\title{
FINANCING OF WATER POLICY: COST RECOVERY OF THE HYDROGRAPHIC CONFEDERATIONS OF SPAIN
}

\author{
MARCOS GARCÍA LÓPEZ, BORJA MONTAÑO SANZ \& JOAQUÍN MELGAREJO MORENO \\ University Institute of Water and Environmental Sciences, University of Alicante, Spain
}

\begin{abstract}
The shortage of water resources and the complex institutional framework in Spain have originated several different organizations responsible for devising water policy measures that have to share the funding. With this distribution of functions, each organization is responsible for some tasks and with funding to perform them. However, taking into account that in Spain the full financing of all aspects of water policy is not achieved, it is understandable that the Hydrographic Confederations are not capable of recovering the costs of their activities. We must add that the distribution of financial resources may not be the most appropriate, which would leave the Hydrographic Confederations in a complicated situation, this paper intends to examine the current financial situation of these organizations. The results of the analysis show that there is a lack of recovery of financial costs in the main activities, which would be offset by a transfer of external funds to the water policy, since this must necessarily be financed. This also implies that, if the environmental costs are added to the financial costs, the result is a very low cost recovery. In addition, there are activity plans that are not being carried out due to the lack of financing, so it seems appropriate to suggest an increase in prices or water pricing to compensate for this lack of funding.

Keywords: Hydrographic Confederations, cost recovery, economic cost, environmental cost, financing of water policy.
\end{abstract}

\section{INTRODUCTION}

Recently, water has ceased to be considered a renewable and infinite resource because, although it is from the natural cycle of water, this feature of the resource has a limit and can become a non-renewable resource if its exploitation is done irresponsibly. In addition, its geographical and temporary distribution is a major problem in Spain, since there are significant imbalances between available resources and water needs in different geographical areas [1].

The increase registered by water supply provisions, together with the increase in population experienced by many urban areas, have made traditional resource sources insufficient [2]. In this way, the development of new sources is key to ensure the sustainability of a fundamental resource such as water, as they increase their availability while reducing the environmental impact derived from the management of water sources.

Currently there are high water stress problems in many parts of the world, including Spain, where there is a considerable dispersion in the distribution of water resources, which leads to great scarcity in a relevant part of the territory and abundance in a few zones. When demand exceeds available resources and their rate of regeneration, strong competition for resources can be expected, leading to scarcity and high pressure on resources, thus increasing the likelihood of conflicts and management and pollution problems, having a negative impact on health and economic activity. Therefore, the growing scarcity leads to greater vulnerabilities of the economy in situations of drought and to a growing deterioration in the environmental quality of surface and underground water bodies [1].

Another important aspect to assess is that the incidence of droughts in Europe is not stable, but has increased by $20 \%$ since 1976 and, despite the increase in torrential rains, annual rainfall has to fall [3]. The overexploitation of the aquifers must be added to the droughts and 
precipitations, so that the need to take water policy measures is evident, since water is a fundamental resource and its correct exploitation is at the base of sustainable development, besides being social demand base [4].

These problems make the situation difficult to solve and even worse when taking into account that in Spain there is a large institutional network. The different organisms that are part of this network have different areas of activity, in particular, we have international, European, national, regional, provincial and local institutions, in addition to the hydrographic confederations and others such as the irrigation communities.

The presence of so many institutions leads to problems of overlapping of competences and functions, conflicts, dilution of responsibilities and shows tendency to create new ones instead of modifying existing ones [5]. These problems, derived from the large number of bodies with responsibilities in terms of water policy, lead to inefficiency in management of water resources. In addition, in line with the objective of this work, the existence of so many entities, with their distribution of competences, implies the need to distribute the financial funds so that everyone can carry out their tasks. Therefore, the funds must be sufficient to finance all water policy measures, but they must be distributed appropriately.

The hydrographic confederations are a fundamental part of the aforementioned institutions, which have diverse and very important functions, for which reason their adequate financing is fundamental for the correct elaboration and execution of water policy. Therefore, this paper will analyse the economic situation of these organizations after commenting on the importance of cost recovery.

\section{IMPORTANCE OF COST RECOVERY}

Water policy is of fundamental importance in society, since water is a basic resource without which could not continue running. This makes water policy a key aspect as it is responsible for the management of water resources and, like any other policy, has an associated high cost that must be financed. When analysing these costs, a distinction must be made between two types, some derived from the need for financial resources to be able to carry out the different activities, while others arise from the need to combat the environmental impact of water policy executed, that is, you can differentiate between economic and environmental costs. As is logical, the new policies must be cautiously elaborated to carry them out in the most efficient way possible, so that their economic cost, but also environmental cost, can be minimized.

The economic costs do not require much explanation, because like any activity, the water policy has an economic cost and requires financing to be able to run. However, the environmental costs are a more complex problem, which is why the latter are going to be treated.

The impact on the natural environment is defined by the Water Framework Directive (WFD), which establishes that an activity, to the extent that it influences on the state of the ecosystems, has an environmental impact that must be corrected. This directive, in the application of "polluter pays", establishes the principle of cost recovery, both economic and environmental [6]. With this, the European Union emphasise the importance of adequate financing of water policy, so that the water supply is economically and environmentally sustainable.

One of the main problems in terms of environmental costs is the great difficulty in calculating them, since it is very complicated to measure the value of natural resources due to their economic, environmental, social and cultural character [5]. In addition, the forms that the environmental impact can adopt are very varied and can affect differently to each type of value, which complicates the development of appropriate measures for their correction. As 
an example, Yongguan et al. [7] analysed the environmental cost of water pollution in the Chinese city of Chongqing, finding that it has significant effects on health, plants, fish, animals and industry, from which is derived not only a negative environmental effect, but also economic losses.

However, there is a relevant aspect that should not be forgotten about the environmental objectives of water policy. The WFD, in search of economic and use of resources efficiency, gives the possibility of eliminating this type of objectives if the economic cost necessary to comply with it is too high for the benefit of achieving it, thus placing more emphasis on the efficient performance of the analyses and actions that are required. In addition, the measures considered must be well received by the public, that is, public preferences must be included in the analysis and decision-making processes [8].

Even if the environmental benefits are taken into account, the economic costs must be financed and the environmental impact must be counteracted, so the economic income is necessary for the water policy, which comes from the price of water and the taxes on water consumption, which is reflected in the water bill. In addition, these revenues must be properly distributed among the different agencies that have assigned water policy responsibilities.

The DMA establishes the recovery of all costs as mandatory, since it is considered as a key to the sustainability of water resources. In terms of economic costs, the financing of these is necessary so that the water policy can continue to be implemented, while the environmental ones suppose a damage on the natural environment that we can't ignore and allow it to accumulate, but repair it to enjoy an environment in good conditions.

However, talking about the economic costs, the WFD does not seek to establish a ranking of cost recovery and a strict criterion, but the objective is to provide the water policy with the necessary resources to carry it out [9]. One aspect to highlight is about who is contributing, since must be the users who enjoy the water services who must pay for its maintenance, while those responsible for the environmental damage must bear the cost of its correction. However, if full costs recovery is not achieved through the usual income from water services, the remaining funding will come from users who are paying in another way, so a tax adjustment would be advisable to make financing fairer.

In order to study the current situation of cost recovery, in the next two sections will be used the cost recovery chapters or annexes of the Spanish inter-community hydrographic confederations for the hydrological cycle 2015-2021 and the recently published documents, in public consultation phase, of the plans for the 2021-2027 cycle, thus being able to compare between both plans.

\section{COST RECOVERY IN THE SPANISH INTER-COMMUNITY HYDROGRAPHIC CONFEDERATIONS}

In this section are analysed the cost recovery data of the inter-community Hydrographic Confederations of Spain for the hydrological cycle 2015-2021, in order to examine the financial situation in this period. Since all the inter-community confederations of the country are included, the recovery data are very high and only those related to the totality of the water services will be included in this study, without specifying the level of recovery in each of them. In addition, to consider the effect of environmental impact, cost recovery is shown in terms of recovery of financial and total costs.

The available data are shown in Table 1, reflecting that an important part of the financial costs is pending to recover and that the level of total costs recovery is far from $100 \%$ when taking into account the environmental and the resource ones. Specifically, it can be seen that the highest level of cost recovery comes from the Tajo Hydrographic Confederation with $91 \%$ of the financial and $81 \%$ of the total. For its part, the Miño-Sil Hydrographic 
Confederation only recovers $38 \%$ of the financial and $34 \%$ of the total costs, which not only represents an important difference compared to the majority, but in this case the cost recovery is really low.

Table 1: Recovery of costs, total and financial, of the Spanish Inter-community Hydrographic Confederations for the hydrological cycle 2015-2021. (Source: Own elaboration based on data from the Inter-community Hydrographic Confederations.)

\begin{tabular}{|l|c|c|}
\hline \multicolumn{3}{|c|}{ Plan 2015-2021 } \\
\hline Hydrographic Confederation & Financial costs & Total costs \\
\hline Cantábrico Occidental & $85 \%$ & $76 \%$ \\
\hline Cantábrico Oriental & $74 \%$ & $67 \%$ \\
\hline Ceuta & $69 \%$ & $56 \%$ \\
\hline Melilla & $41 \%$ & $40 \%$ \\
\hline Duero & $64 \%$ & $49 \%$ \\
\hline Ebro & $76 \%$ & $65 \%$ \\
\hline Guadalquivir & $83 \%$ & $74 \%$ \\
\hline Guadiana & $80 \%$ & $59 \%$ \\
\hline Tajo & $91 \%$ & $81 \%$ \\
\hline Júcar & $84 \%$ & $78 \%$ \\
\hline Segura & $83 \%$ & $57 \%$ \\
\hline Miño-Sil & $38 \%$ & $34 \%$ \\
\hline
\end{tabular}

Note: Information regarding the data used in this table can be found in the Appendix.

The rest of the confederations are distributed among the levels of cost recovery of the Tajo and the Miño-Sil, but, in general, closer to the level of the former. Taking into account these confederations, the unweighted average recovery of financial and total costs is $72 \%$ and $61 \%$, respectively. Therefore, there is a reduction in the level of cost recovery of 11 points by adding environmental costs to financial ones, which shows their relevance. However, this change is, again, an unweighted average, so there are confederations with larger and lower variations. Among these variations we can highlight the percentage point of Melilla and the 4 of the Miño-Sil which, although they are the two confederations with the least cost recovery, are the ones that see their situation less worsened by incorporating environmental costs. On the other hand, the large variations of 21 and 25 percentage points of Guadiana and Segura, respectively, are important.

The results, obtained by the confederations themselves, show a lack of capacity to finance the water policy carried out in Spain, even some of these organizations have prepared additional water policy measures that are not being implemented due to lack of income. This fact leads, as mentioned above, to the fact that the current situation of water resources cannot be considered sustainable, since the water policy is not being fully financed and does not adequately address the environmental impact of human water resources management. In addition, it must be kept in mind that the water policy must necessarily be financed, so that in order to complete the cost recovery, funds will be received from other ways independent of water services. In this way, people other than consumers are paying to maintain the situation, which implies that the polluter pays principle is not being met.

It must also be considered that this lack of funding may be blocking the execution of additional measures and the internalization of environmental costs. As explained by the Segura Hydrographic Confederation [10]: "there is a pending environmental cost (future) and 
another already internalized, corresponding to the measures already executed and included in the financial costs". In other words, the environmental costs are not fully internalized because certain measures cannot be implemented, hence the distinction between financial and environmental costs of the data.

\section{COMPARISON OF THE CURRENT PLANS WITH THE PUBLISHED DATA OF THE NEXT ONES}

In this section, taking advantage of the recent publication last October of the initial documents of hydrological planning for the 2021-2027 period, a comparison is made between the levels of cost recovery of the current cycle with those of the next. Table 2 shows the recovery levels of both financial and total costs for both hydrological cycles, showing first the financial ones and, second, the totals of both cycles.

Table 2: Cost recovery, total and financial, of the Spanish inter-community hydrographic confederations for the hydrological cycles 2015-2021 and 2021-2027. (Source: Own elaboration based on data from the Inter-community Hydrographic Confederations.)

\begin{tabular}{|l|c|c|c|c|}
\hline Cost recovery* & \multicolumn{2}{|c|}{ Financial costs } & \multicolumn{2}{c|}{ Total costs } \\
\hline $\begin{array}{l}\text { Hydrographic } \\
\text { Confederations }\end{array}$ & $2015-2021$ & $2021-2027 * *$ & $2015-2021$ & $2021-2027 * *$ \\
\hline Cantábrico Occidental & $85 \%$ & $86 \%$ & $76 \%$ & $77 \%$ \\
\hline Cantábrico Oriental & $74 \%$ & $79 \%$ & $67 \%$ & $74 \%$ \\
\hline Ceuta & $69 \%$ & $68 \%$ & $56 \%$ & $66 \%$ \\
\hline Melilla & $41 \%$ & $37 \%$ & $40 \%$ & $37 \%$ \\
\hline Duero & $64 \%$ & $82 \%$ & $49 \%$ & $49 \%$ \\
\hline Ebro & $76 \%$ & $83 \%$ & $65 \%$ & $70 \%$ \\
\hline Guadalquivir & $83 \%$ & $84 \%$ & $74 \%$ & $79 \%$ \\
\hline Guadiana & $80 \%$ & $71 \%$ & $59 \%$ & $50 \%$ \\
\hline Tajo & $91 \%$ & $88 \%$ & $81 \%$ & $73 \%$ \\
\hline Júcar & $84 \%$ & $93 \%$ & $78 \%$ & $87 \%$ \\
\hline Segura & $83 \%$ & $82 \%$ & $57 \%$ & $63 \%$ \\
\hline Miño-Sil & $38 \%$ & $49 \%$ & $34 \%$ & $47 \%$ \\
\hline
\end{tabular}

Notes: * Data is rounded. ** In some cases, in the documents under public consultation for the planning of the next hydrological cycle (2021-2027) data on cost recovery of the current cycle have varied slightly, but it has been chosen to maintain the memory data of the current hydrological plan because in these new documents only the data of total costs recovery of the current plans are offered, leaving out the distinction between financial and environmental costs. Information regarding the data used in this table can be found in the Appendix.

In general, the conclusions obtained through the data of the current period can be extended to the new data, although with some differences. Taking into account the change in recovery of financial costs from one period to another, we find both positive and negative variations, with 7 confederations that improve their situation compared to 5 that worsen, with 3 percentage points as unweighted average of these variations. Thus, we can see important improvements like the 18 points of the Duero and the 11 points of the Miño-Sil, but also setbacks like the 9 points of the Guadiana, which is the only place with such a high negative change.

On the other hand, taking the total costs the result is similar because now 8 confederations improve their situation by 3 that make it worse, while one maintains the total costs recovery 
in both cycles, being now the average of variation the same as for financial costs. In this case, we find again significant improvements, highlighting the 13 points of the Miño-Sil and the 10 points of Ceuta, but there are two strong negative variations, specifically the Guadiana and the Tajo with variations of 9 and 8 points, respectively. These last two, together with Melilla, which drops 3 points, are the only ones that see worsened their situation.

However, one aspect to note is that there are three confederations with opposite variations in cost recovery. In the first place, Ceuta worsened its financial costs recovery at one point, but improved the recovery of the totals by 10 points, showing a better environmental situation. Second, the Duero, with an improvement of 18 points in the financial costs recovery, has a variation of tenths in terms of totals. This is due to a greater decrease in financial costs than in revenues, however, the recovery of total costs barely varies due to the reduced improvement in the environmental cost, which acquires a greater weight in the accounts. Finally, the Segura, with a 1 point reduction in financial costs recovery, obtains an improvement of 7 points in terms of the total costs recovery.

Again, the data of the confederations themselves show inability to recover financial and environmental costs, in addition to the internalization of the latter, which compromises the sustainability of water resources and allows, again, to propose an increase in the price of water. water services or another source of income for water policy.

\section{CONCLUSIONS}

Water resources are currently a scarce resource that requires a large number of water policy measures to manage it efficiently. This is of great importance, because water is a fundamental resource without which human activity could not develop. Of course, these measures have an economic cost that must be financed by necessity, but also the environmental impact that human activity has on the environment must be addressed, so an additional economic cost must be considered depending on the one that has to repair the damage caused. The recovery of these costs is necessary to be able to consider the water policy as sustainable.

To execute the measures, in Spain there is a large number of institutions that share the functions and income, so that each of them can carry out its activity. Therefore, the proper distribution of financing between institutions is as important as obtaining it. Observing the data of the Spanish inter-community hydrographic confederations, it can be concluded that cost recovery is not being achieved, without even reaching the recovery of financial costs, so that the activity currently is not sustainable and there are still important efforts to be made. To conclude more accurately that the recovery of water policy costs is not being achieved it would be necessary to analyse a greater number of institutions, but it can be concluded that no Spanish inter-community hydrographic confederation recovers them, reflecting a structural problem in this area.

In sum, water policy at the river basin level is not adequately financed and requires more funds from water resources to avoid obtaining them from other places. The latter is relevant because service users are those who must pay for it instead of other individuals or agents. As a recommendation, it seems appropriate to propose an increase in the price of water and/or in the taxes levied on its consumption to improve the situation, since the current price of water does not respond to the scarcity and importance of this resource.

\section{APPENDIX}

- Confederación Hidrográfica de Ceuta, Memoria. Plan hidrológico de la Demarcación Hidrográfica de Ceuta, 2015. www.chguadalquivir.es/demarcacion-hidrograficaceuta\#Segundociclodeplanificaci\%C3\%B3n(2016-2021). Accessed on: 7 Feb. 2019. 
- Confederación Hidrográfica de Ceuta, Documentos iniciales. Memoria. Plan hidrológico de la Demarcación Hidrográfica de Ceuta. Revisión de tercer ciclo (2021-2027), 2018. www.chguadalquivir.es/demarcacion-hidrografica-ceuta. Accessed on: 7 Feb. 2019.

- Confederación Hidrográfica de Melilla, Memoria. Plan hidrológico de la Demarcación Hidrográfica de Melilla, 2015. www.chguadalquivir.es/demarcacion-hidrograficamelilla\#Segundociclodeplanificaci\%C3\%B3n(2016-2021). Accessed on: 7 Feb. 2019.

- Confederación Hidrográfica de Melilla, Documentos iniciales. Memoria. Plan hidrológico de la Demarcación Hidrográfica de Melilla. Revisión de tercer ciclo (20212027), 2018. www.chguadalquivir.es/demarcacion-hidrografica-melilla. Accessed on: 7 Feb. 2019.

- Confederación Hidrográfica del Cantábrico, Anejo 09. Recuperación de costes de los servicios del agua. Plan hidrológico de la Demarcación Hidrográfica del Cantábrico Occidental 2015-2021, 2015. www.chcantabrico.es/dhc-occidental. Accessed on: 7 Feb. 2019.

- Confederación Hidrográfica del Cantábrico, Memoria. Plan hidrológico de la parte española de la Demarcación Hidrográfica del Cantábrico Oriental, 2015. www.chcantabrico.es/parte-espaniola-de-la-dhc-oriental. Accessed on: 7 Feb. 2019.

- Confederación Hidrográfica del Cantábrico, Documentos iniciales. Memoria. Plan hidrológico de la Demarcación Hidrográfica del Cantábrico Occidental. Revisión de tercer ciclo (2021-2027), 2018. www.chcantabrico.es/planes-hidrologicos-20212027/dhc-occidental/documentos-iniciales. Accessed on: 7 Feb. 2019.

- Confederación Hidrográfica del Cantábrico, Documentos iniciales. Memoria. Plan hidrológico de la parte española de la Demarcación Hidrográfica del Cantábrico Oriental. Revisión de tercer ciclo (2021-2027), 2018. www.chcantabrico.es/planeshidrologicos-2021-2027/dhc-oriental/documentos-iniciales. Accessed on: 7 Feb. 2019.

- Confederación Hidrográfica del Duero, Memoria de Plan hidrológico 2015-2021. Plan hidrológico de la parte española de la Demarcación Hidrográfica del Duero, 2015. www.chduero.es/Inicio/Planificaci\%C3\%B3n/Planhidrol\%C3\%B3gico20152021/Plan Hidrol\%C3\%B3gico/tabid/734/Default.aspx. Accessed on: 7 Feb. 2019.

- Confederación Hidrográfica del Duero, Documentos iniciales. Memoria. Plan hidrológico de la parte española de la Demarcación Hidrográfica del Duero. Revisión de tercer ciclo (2021-2027), 2018. www.chduero.es/Inicio/Planificaci\%C3\%B3n/ Planhidrol\%C3\%B3gico20222027Propuesta/Documentosiniciales/tabid/767/Default.as px. Accessed on: 7 Feb. 2019.

- Confederación Hidrográfica del Ebro, Memoria. Plan hidrológico de la parte española de la Demarcación Hidrográfica del Ebro, 2015. www.chebro.es/contenido.visualizar.do ?idContenido=42695\&idMenu=4780. Accessed on: 7 Feb. 2019.

- Confederación Hidrográfica del Ebro, Documentos iniciales. Memoria. Plan hidrológico de la parte española de la Demarcación Hidrográfica del Ebro. Revisión de tercer ciclo (2021-2027), 2018.

www.chebro.es/contenido.visualizar.do?idContenido $=56837 \& i d M e n u=5781$. Accessed on: 7 Feb. 2019.

- Confederación Hidrográfica del Guadalquivir, Memoria. Plan hidrológico de la Demarcación Hidrográfica del Guadalquivir, 2015. www.chguadalquivir.es/ demarcacion-hidrografica-guadalquivir\#Segundociclodeplanificaci\%C3\%B3n(20162021). Accessed on: 7 Feb. 2019.

- Confederación Hidrográfica del Guadalquivir, Documentos iniciales. Memoria. Plan hidrológico de la Demarcación Hidrográfica del Guadalquivir. Revisión de tercer ciclo 
(2021-2027), 2018. www.chguadalquivir.es/demarcacion-hidrografica-guadalquivir. Accessed on: 7 Feb. 2019.

- Confederación Hidrográfica del Guadiana, Memoria (Parte II). Plan hidrológico de la Demarcación Hidrográfica del Guadiana, 2015.

http://planhidrologico2015.chguadiana.es/?corp=planhidrologico2015\&url=61.

Accessed on: 7 Feb. 2019.

- Confederación Hidrográfica del Guadiana, Documentos iniciales. Memoria. Plan hidrológico de la Demarcación Hidrográfica del Guadiana. Revisión de tercer ciclo (2021-2027), 2018. www.chguadiana.es/planificacion/plan-hidrologico-de-lademarcacion/revision-del-plan-hidrologico-2021-2027/documentos-iniciales. Accessed on: 7 Feb. 2019.

- Confederación Hidrográfica del Júcar, Memoria. Plan hidrológico de la Demarcación Hidrográfica del Júcar, 2015. www.chj.es/es-es/medioambiente/planificacionhidrologica/Paginas/PHC-2015-2021Plan-Hidrologico-cuenca.aspx. Accessed on: 7 Feb. 2019.

- Confederación Hidrográfica del Júcar, Documentos iniciales. Memoria. Plan hidrológico de la Demarcación Hidrográfica del Júcar. Revisión de tercer ciclo (2021-2027), 2018. www.chj.es/es-es/medioambiente/planificacionhidrologica/Paginas/PHC-2021-2027Indice.aspx. Accessed on: 7 Feb. 2019.

- Confederación Hidrográfica del Miño-Sil, Capítulo 9. Recuperación de costes de los servicios del agua. Plan hidrológico de la Demarcación Hidrográfica del Miño-Sil, 2015. www.chminosil.es/es/chms/planificacionhidrologica/plan-hidrologico-2015-2021vigente-rd-1-2016/80-chms/1359-plan-hidrologico-2015-2021-rd-1-2016. Accessed on: 7 Feb. 2019.

- Confederación Hidrográfica del Miño-Sil, Documentos iniciales. Memoria. Plan hidrológico de la Demarcación Hidrográfica del Miño-Sil. Revisión de tercer ciclo (2021-2027), 2018. www.chminosil.es/es/chms/planificacionhidrologica/consultapublica-documentos-iniciales-2021-2027. Accessed on: 7 Feb. 2019.

- Confederación Hidrográfica del Segura, Documentos iniciales. Memoria. Plan hidrológico de la Demarcación Hidrográfica del Segura. Revisión de tercer ciclo (20212027), 2018.

www.chsegura.es/chs/planificacionydma/planificacion21-27/proceso.html. Accessed on: 7 Feb. 2019.

- Confederación Hidrográfica del Tajo, Anejo 09. Recuperación de costes de los servicios del agua en la Demarcación Hidrográfica del Tajo. Plan hidrológico de la parte española de la Demarcación Hidrográfica del Tajo 2015-2021, 2015. www.chtajo.es/ LaCuenca/Planes/PlanHidrologico/Planif_2015-2021/Paginas/Plan_2015-2021.aspx. Accessed on: 7 Feb. 2019.

- Confederación Hidrográfica del Tajo, Documentos iniciales. Memoria. Plan hidrológico de la parte española de la Demarcación Hidrográfica del Tajo. Revisión de tercer ciclo (2021-2027), 2018. www.chtajo.es/LaCuenca/Planes/PlanHidrologico/Planif_20212027/Paginas/default.aspx. Accessed on: 7 Feb. 2019.

\section{REFERENCES}

[1] Prats, D., La reutilización de aguas depuradas regeneradas a escala mundial: análisis y prospectivas. Agua y Territorio, 8, pp. 10-21, 2016.

[2] Melgarejo, J., Efectos ambientales y económicos de la reutilización del agua en España. CLM Economía, 15, pp. 245-270, 2009. 
[3] Navarro, T., Water reuse and desalination in Spain: Challenges and opportunities. Journal of Water Reuse and Desalination, 8(2), pp. 153-168, 2018. DOI: $10.2166 /$ wrd.2018.043.

[4] Trapote, A., Tecnologías de depuración y reutilización: nuevos enfoques. Agua y Territorio, 8, pp. 48-60, 2016.

[5] Torregrosa, T., Valoración económica de los recursos naturales. Masters thesis in Applied Economics, Universidad de Alicante, Spain, 2017.

[6] European Union, Directive 2000/60/EC of the European Parliament and of the Council of 23 October 2000 establishing a framework for Community action in the field of water policy. https://eur-lex.europa.eu/eli/dir/2000/60/oj?locale=en. Accessed on: 7 Feb. 2019.

[7] Yongguan, C., Seip, H.M. \& Vennemo, H., The environmental cost of water pollution in Chongqing, China. Environment and Development Economics, 6(3), pp. 313-333, 2001. DOI: $10.1017 / \mathrm{S} 1355770 \mathrm{X} 01000183$.

[8] Alcon, F., Martin-Ortega, J., Berbel, J. \& De Miguel, M.D., Environmental benefits of reclaimed water: an economic assessment in the context of the Water Framework Directive. Water Policy, 14(1), pp. 148-159, 2012. DOI: 10.2166/wp.2011.001.

[9] Villar, A., Reutilización de aguas regeneradas: aproximación a los costes de producción y valoración de su uso. Agua y Territorio, 8, pp. 70-79, 2016.

[10] Confederación Hidrográfica del Segura, Memoria. Plan hidrológico de la Demarcación Hidrográfica del Segura 2015-2021, 2015.

www.chsegura.es/chs/planificacionydma/planificacion15-21/ Accessed on: 7 Feb. 2019. 